\title{
Mesangial cells in membranous glomerulonephritis
}

\author{
P. A. PORTCH AND G. WILliamS
}

From the Department of Pathology, University of Manchester

SYNOPSIS Renal biopsies of seven patients with membranous glomerulonephritis were examined by light, electron, and immunofluorescence microscopy. All had characteristic changes of glomerular basement membranes, typically with bright granular membranous fluorescence of IgG and variable deposits of complement. Cellularity was normal or slightly increased due largely to mesangial cell proliferation. These cells assumed a variety of appearances referred to as resting, hyperactive, and 0 dark. Resting forms occurred in cases with normal cellularity and limited complement deposition. Hyperactive cells showed ultrastructural evidence of increased secretory and digestive activity and 8 were associated with proliferation and more pronounced complement deposition. Dark cells, inter- $\mathrm{O}$ preted as undergoing shrinkage and degeneration, were found in small numbers in all biopsies.

The characteristic glomerular lesion in membranous glomerulonephritis is a diffuse and fairly uniform thickening of the capillary walls without significant cellular proliferation. This results from the deposition of complexes in which immunoglobulins and complement can be demonstrated by immunofluorescence (McCluskey, 1969). These immune complexes occur mainly in a subepithelial position, separated by outward projections of the basement membrane which give spiky profiles to the membranes in sections stained with methenamine silver (Brewer, 1964). These prominent membrane changes have overshadowed the less obvious cellular ones in the glomeruli in this nephropathy. In this study of seven cases of membranous glomerular disease, the morphology of the mesangial cells has been investigated.

\section{Materials and Methods}

Kidney tissue was obtained by percutanous needle

Received for publication 29 June 1973. biopsy from seven patients (table I) with membranous glomerulonephritis. In all cases, clinical indications of systemic lupus erythematosus were absent; in four, the onset was insidious with no preceding infections. One however, had a sore throat, and another a long history of tonsillitis before onset. $\mathbf{m}$ the other case intrarenal vein thrombosis was found at biopsy. Only one patient had a family history of renal disease.

Small pieces of tissue from each end of a biopsy $\triangle$ core were processed for electron microscopy; the $\overrightarrow{\overline{0}}$ remainder was bisected longitudinally, one piece being used for light and the other for immunofluorescence microscopy.

\section{LIGHT MICROSCOPY}

Tissue was embedded in paraplast by normal histological methods, and 1-2 $\mu$ m-thick sections were cut $\dot{\delta}$ after both block and knife had been cooled in a refrigerator. Sections were stained with haema- 0 toxylin and eosin (HE), periodic acid Schiff (PAS), Martius yellow, soluble blue, brilliant scarlet (MSB), and methenamine silver (MS).

\begin{tabular}{|c|c|c|c|c|}
\hline Patient & $\operatorname{Sex}$ & Age at Biopsy (yr) & Duration of Renal Symptoms & Onset of Nephrotic Syndrome \\
\hline 1 & $\mathbf{M}$ & 35 & 6 months & $\begin{array}{l}\text { Recurrent tonsillitis for } 18 \text { years before onset; family history of } \\
\text { renal disease }\end{array}$ \\
\hline 2 & $\mathbf{M}$ & 56 & 3 years & Insidious \\
\hline 3 & $\mathbf{F}$ & 34 & 10 years & Insidious \\
\hline 4 & $\mathbf{F}$ & 50 & $1 \frac{1}{2}$ years & Insidious \\
\hline 5 & $\mathbf{M}$ & 31 & 6 months & Six weeks' sore throat before onset \\
\hline 6 & $\mathbf{F}$ & 17 & 2 years & Insidious \\
\hline 7 & $\mathbf{M}$ & 64 & 4 months & Insidious; thrombosis of intrarenal veins in biopsy \\
\hline
\end{tabular}




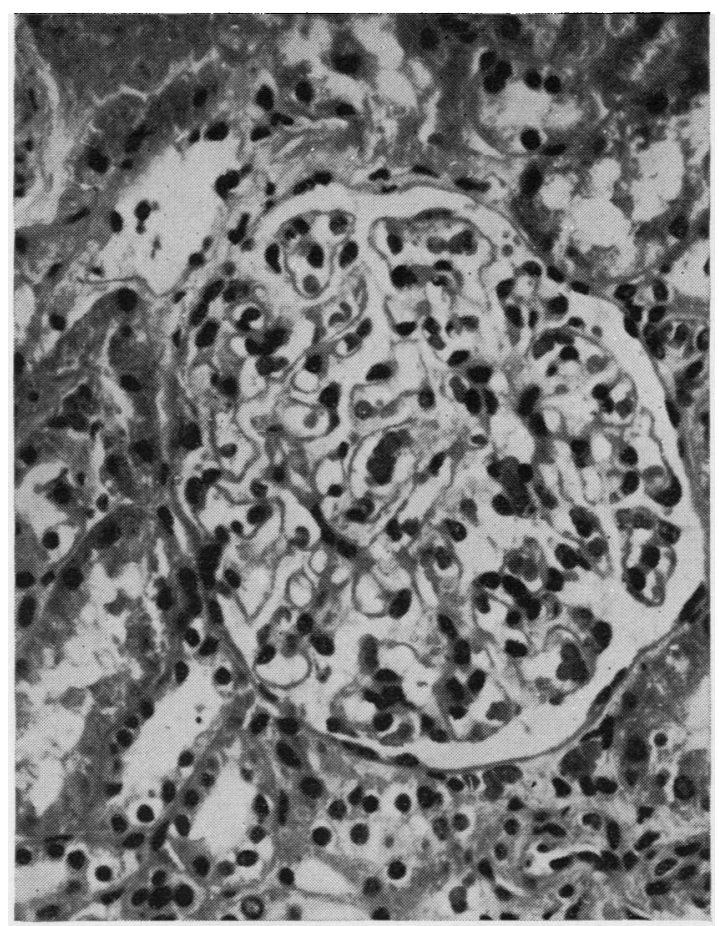

Fig 1 Case 1: glomerulus showing diffuse capillary wall thickening without cellular proliferation $(H E \times 300)$.

IMMUNOFLUORESCENCE MICROSCOPY

Cryostat sections, 3-4 $\mu \mathrm{m}$ thick, were prepared from tissue snap frozen in a mixture of isopentane and cardice, and were fixed for one minute in acetone. The sections were stained by the direct technique (Coons and Kaplan, 1950), with commercially prepared FITC-conjugated antisera to $\operatorname{IgG}$, IgA, IgM, $\beta \mathrm{IC} / \mathrm{IA}$, and fibrinogen. Unconjugated blocking control antisera were also used. Glomerular fluorescence was scored semiquantitatively on a six-point scale $(0,+l-,+,++,+++,++++)$.

\section{ELECTRON MICROSCOPY}

Tissue was fixed in $2.5 \%$ buffered glutaraldehyde for four hours, postfixed in cold $1 \%$ osmium tetroxide for one hour, dehydrated in graded alcohols, and embedded in araldite according to the method of Luft (1961). Sections $0.5 \mu \mathrm{m}$ thick were stained with toluidine blue for tissue recognition and ultrathin (silver/gold) sections were cut from suitable blocks. These were mounted on uncoated copper grids and double stained with uranyl acetate (Watson, 1958) and lead citrate (Reynolds, 1963). Alternatively, some sections were stained with alcoholic $0.5 \%$ phosphotungstic acid (PTA) for collagen (Pease,

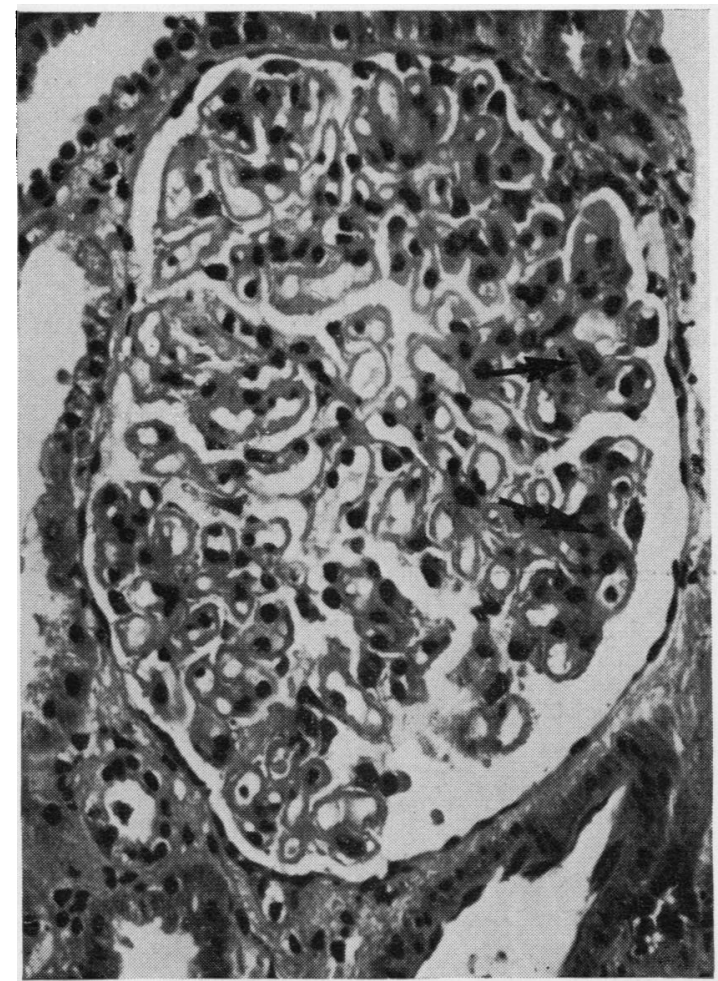

Fig 2 Case 5: glomerulus with diffuse capillary wall thickening and hypercellularity particularly involving the mesangial cells. The mesangial matrix is also widened (arrows) $(H E \times 300)$.

1964). The grids were examined with an AEI EM6B electron microscope. When possible at least two glomeruli from each case were studied.

\section{Results}

\section{LIGHT MICROSCOPY}

Characteristic thickening of the glomerular capillary wall (Heptinstall, 1966; Rosen, 1971) was seen in all the biopsies (figs 1 and 2), with numerous subepithelial humps and small intramembranous vesicles visible after MS staining. Toluidine blue showed dark spots in the glomerular basement membrane corresponding to the vesicles and the areas between the humps. Some splitting of the glomerular basement membrane by material giving staining reactions suggestive of cytoplasm was seen, especially in cases 5 and 6.

The glomeruli in two cases ( 1 and 2 ) had normal, or possibly slightly reduced cellularity (fig 1 ), and a slight increase of mesangial matrix. Cell counts gave values within the normal limits calculated by 
Fig 3 Case 4: glomerulus treated with FITC conjugated anti IgG serum showing characteristic diffuse granular, membranous fluorescence. There is also some mesangial deposition (arrow) $(\times 350)$.

Kawano, Arakawa, McCoy, Porch, and Kimmelstiel (1969). In one case, however (3), there was a trend towards sclerosis of the tuft and reduced cellularity.

Mild cellular proliferation was detectable in the glomeruli of two cases (4 and 7) while the remaining cases showed a moderate proliferation (fig 2) affecting the mesangial cells in particular. There was also thickening of the matıix which was rather focal in case 6 and diffuse in case 5. Lobulation was accentuated in some of the glomeruli in the latter biopsy but the changes were incompatible with those of membrano-proliferative glomerulonephritis (Mandalenakis, Mendoza, Pirani, and Pollak, 1971).

\section{IMMUNOFLUORESCENCE MICROSCOPY}

The most striking feature was the bright immunofluorescence of IgG seen in all except one biopsy (table II) The deposits were diffuse and granular (fig 3) with a similar distribution to those seen in the histological preparations. There was often some mesangial fluorescence.

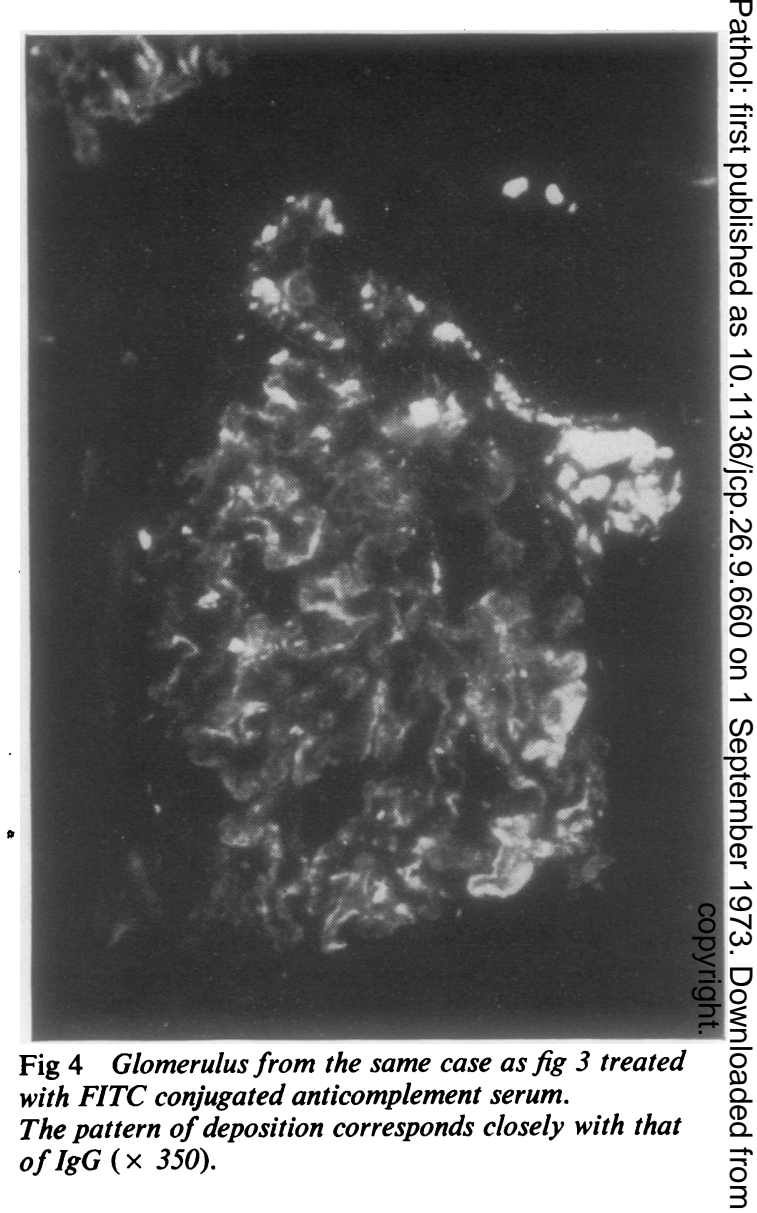

Fluorescence with complement was variable, being? brightest in the biopsies with cellular proliferation? (fig 4). The type of deposit corresponded closely with that of IgG. IgM occurred in most cases, especially:in the mesangia, and occasional granular deposits of 3 IgA were detected in the membranes and mesangia. Fibrinogen, however, was identified in one biopsy3 only, where it was distributed in the mesangia and $\frac{\mathrm{O}}{2}$ capillary lumens.

\section{ELECTRON MICROSCOPY}

Mesangial cells

These were characterized by their centrolobular 0 position (fig 5), and by their cytoplasm which ${ }^{N}$ contained characteristic bundles of fine filaments (Trump and Bulger, 1968; Simon and Chatelanat,o 1969), 4-7 $\mathrm{nm}$ in diameter, with dense attachmento areas at cell surfaces (fig 6) similar to those of smooth?

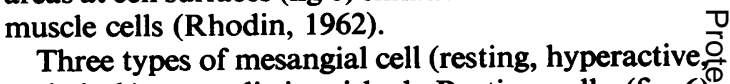
and dark) were distinguished. Resting cells (fig 6$)$ 


\begin{tabular}{|c|c|c|c|c|c|}
\hline \multirow[t]{2}{*}{ Patient } & \multicolumn{5}{|c|}{ Degree of Fluorescence ${ }^{1}$} \\
\hline & $I g G$ & $\operatorname{Ig} A$ & $I g M$ & Beta $I C / I A$ & Fibrinogen \\
\hline $\begin{array}{l}1 \\
2 \\
3 \\
4 \\
5 \\
6 \\
7\end{array}$ & $\begin{array}{l}++++ \\
++++ \\
++ \\
++++ \\
++++ \\
+++ \\
+1-\end{array}$ & $\begin{array}{l}- \\
++ \\
- \\
+1- \\
+1- \\
+ \\
+1-\end{array}$ & $\begin{array}{l}- \\
+ \\
+ \\
+ \\
+ \\
+++ \\
+1-\end{array}$ & $\begin{array}{l}+1- \\
+1- \\
+1- \\
+++ \\
++ \\
+ \\
+\end{array}$ & $\begin{array}{l}- \\
\text { nt } \\
\text { nt } \\
- \\
+1- \\
+1- \\
+\end{array}$ \\
\hline
\end{tabular}

Table II Summary of immunofluorescence results for seven patients with membranous glomerulonephritis

$\mathbf{1}_{\text {nt }}=$ not tested,,,,$++++++++++=$ positive result, $+/-=$ equivocal positivity, $-=$ negative result

had irregularly shaped, sometimes deeply notched nuclei and cytoplasm of medium density with thin cell processes confined to the axial region. Golgi apparatus and rough endoplasmic reticulum were poorly developed. Other cytoplasmic organelles, including a few dense bodies resembling lysosomes (Miller and Palade, 1964), were confined mainly to the juxtanuclear cytoplasm and larger cell processes.

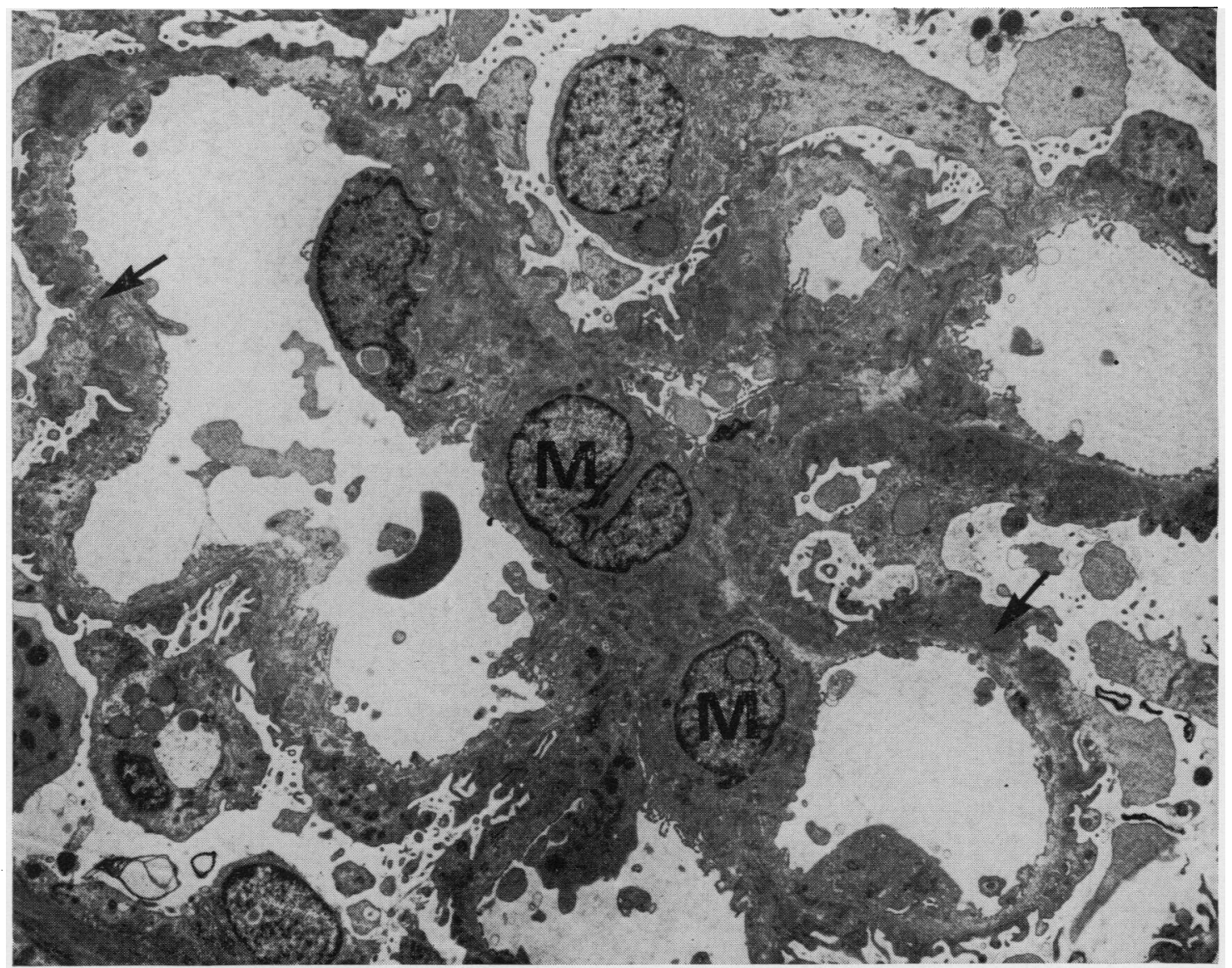

Fig 5 Case 1: low-power electron micrograph showing the deposits (arrows) in the capillary walls and the resulting lumpy thickening of the glomerular basement membrane. Mesangial cells $(\mathrm{M})$ occupy a centrolobular position, and those depicted here are resting forms $(\times 5000)$. 
Cells of this type were found predominantly in cases with normal cell numbers.

Hyperactive mesangial cells had abundant ribosomes (both free and attached), and well developed Golgi apparatus in cytoplasm which ranged in appearance from very pale to rather dense. Pale cells had rounded nuclei and plump cell processes which sometimes extended towards the periphery of capillary loops (fig 7), while images suggestive of phagocytosis were common and numbers of dense bodies were often increased. These cells were found in the cases with the highest cellularity and complement deposition.

With increase in cytoplasmic density (fig 8), cell processes became thinner and more tortuous and were largely confined to the axial regions, while nuclear density increased and nuclear outlines became more irregular. Dense bodies were fewer than in the pale cells although profiles suggestive of phagocytosis were identifiable. Vesicles similar to those surrounding the Golgi apparatus very occasionally appeared to fuse with cell membranes and faint vesicular profiles (50-70 $\mathrm{nm}$ in diameter) lay in the mesangial matrix against the plasmalemma (fig 8). Ribosomes were abundant and there were clusters of larger $(20-30 \mathrm{~nm})$, probably glycogen, granules. Dense hyperactive cells were prominent in biopsies showing mild mesangial cell proliferation, although they also occurred in cases with the highest cellularity.

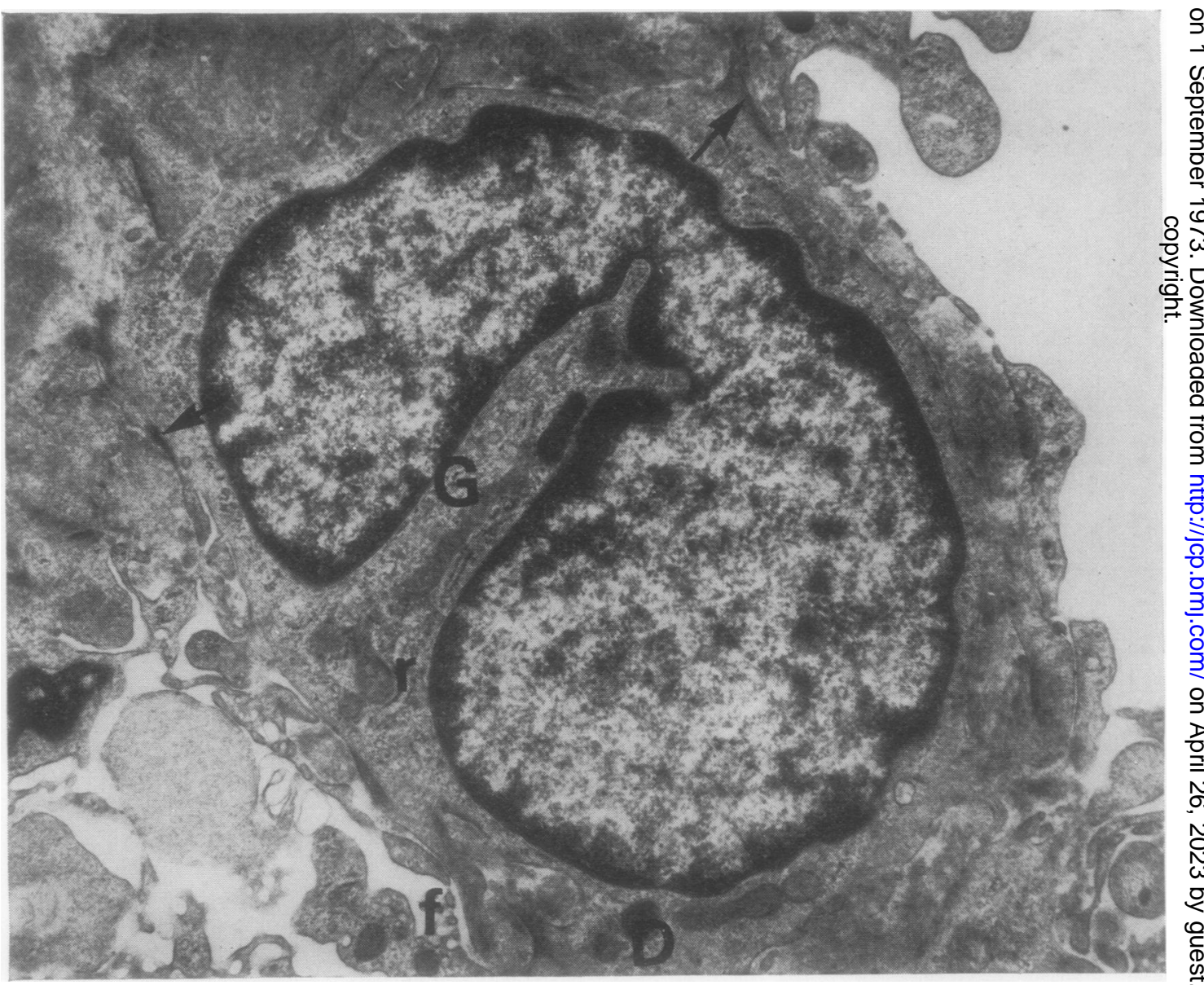

Fig 6 Resting mesangial cell showing irregularly shaped nucleus and poor development of the Golgi apparatus (G) and rough endoplasmic reticulum (r). Occasional dense bodies (D) may be detected. The prominent bundles of fine filaments with dense attachment areas (arrows), and the lack of fenestrated cytoplasm (f) distinguish mesangial cells from endothelial cells parts of which line capillary loops in the upper right and lower left of this micrograph $(\times 18750)$. 
Dark cells (figs 7 and 9) were found in small numbers in most biopsies but were commonest in cases with the largest deposits of complement. They had dense crenellated nuclei and condensed cytoplasm and their organelles included swollen mitochondria and numerous $15-30 \mathrm{~nm}$ particles. In none of the biopsies were cells of haematogenous origin identified either within the mesangium or in abnormal numbers within the capillary lumens.

Mesangial matrix and glomerular basement membrane Mesangial matrices comprising irregularly packed filaments (2-4 $\mathrm{nm}$ diameter) were thickened according to the duration of the disease and the patient's age. Deposits, although often occurring in the lamina densa where it crossed the axial region, could not be identified in the intercellular channels.
The glomerular basement membrane was irregularly thickened in all cases with the lamina densa split and frayed around numerous deposits. The latter could be roughly divided into dense, intermediate, and lucent. Dense deposits occurred immediately below the podocytes (fig 10), sometimes as humps or separated from the epithelium by a strand of lamina densa. Intermediate deposits comprised more loosely packed granular or flocculent material often surrounded by an electron-lucent halo and separated from the podocytes by strands of lamina densa (fig 11). Lucent deposits occurred subendothelially or intramembranously; they were often large, irregularly shaped (figs 10 and 11) and sometimes contained scattered flocculent material and small granules with dense rims and lucent cores containing dense particles $60-70 \mathrm{~nm}$ in diameter.

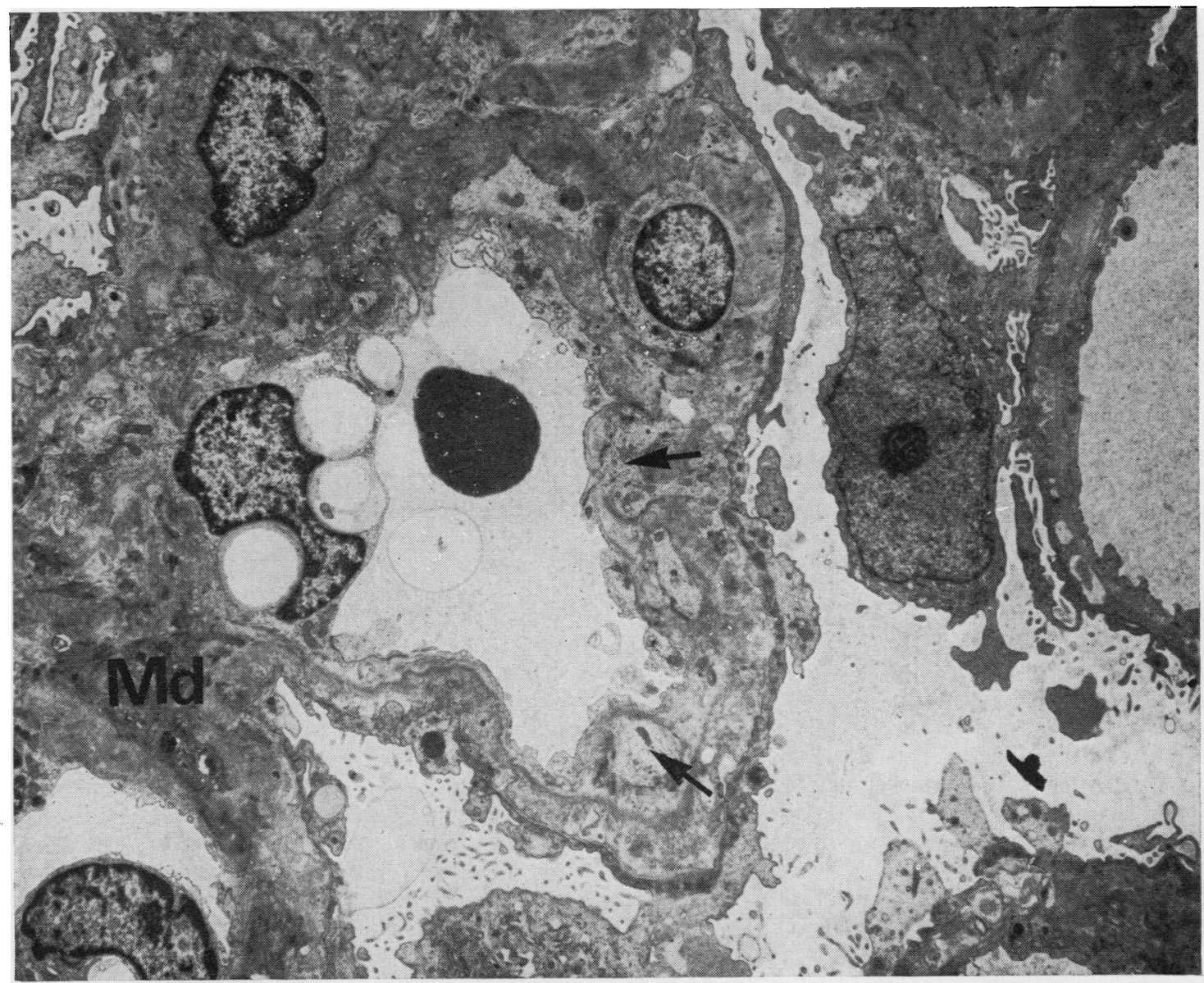

Fig 7 Pale hyperactive cell with cytoplasmic processes which have spread into the glomerular basement membrane (arrows). Note also part of a dark mesangial cell $(\mathrm{Md})(\times 5000)$. 


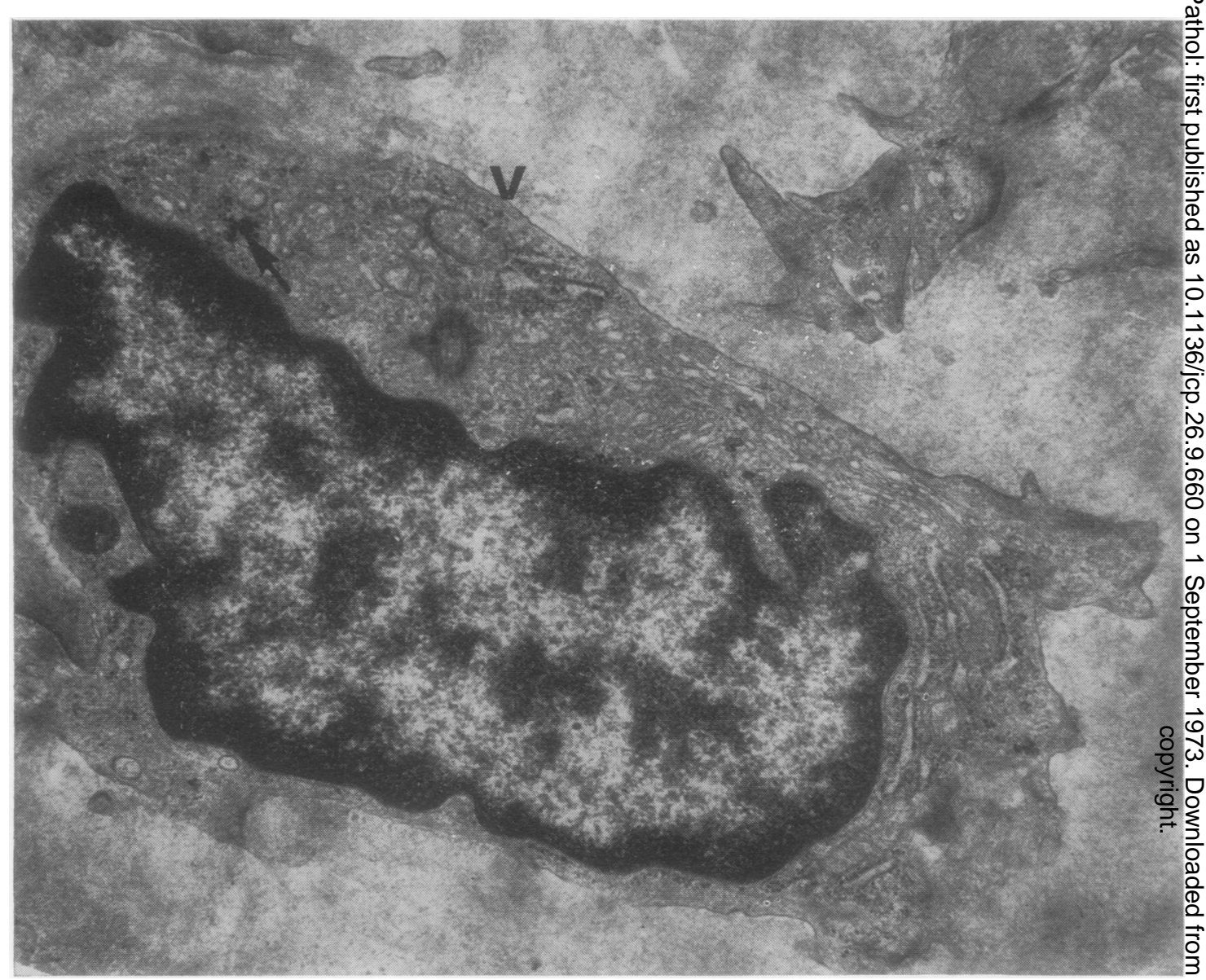

Fig 8 Dense hyperactive mesangial cell. Pseudopods are reduced, and the nuclear outline is irregular, but rough endoplasmic reticulum and Golgi apparatus are still well developed. Faint vesicular profiles (V) lie in the mesangial matrix against the plasmalemma, and the cytoplasm contains dense particles which are probably glycogen granules (arrow) $(\times 18750)$.

\section{Discussion}

All the patients in this study were judged to have membranous glomerulonephritis by histological criteria. None had evidence of systemic lupus erythematosus.

The irregular, lumpy thickening of the glomerular basement membrane was visible with the light microscope, and ultrastructurally dense, intermediate, and lucent deposits could be detected. It was thought that initial dense, subepithelial, often hump-like deposits became covered by a layer of lamina densa and evolved into intermediate deposits and finally formed lucent areas. Similar findings have been reported by Churg, Grishman, Goldstein, Yunis, and Porush (1965) and Ehrenrech and Churg (1968) although the deposits did not appear to be replacedB by basement membrane as these workers suggested 0

There was good correlation between the light, immunofluorescence and electron microscopie results: bright granular membranous fluorescence of IgG was seen in all but one of the biopsies, ando corresponded particularly with the intermediate and dense deposits. This is in accord with the findings in experimental models (reviewed by McCluskey and Vassalli, 1969), and in human membranous glomerulonephritis (McCluskey, Vassalli, Gallo and Baldwin, 1966; Rosen, 1971), and is compatible? with the theory of immune complex deposition as the basis of the disease (Dixon, Feldman, and Vazquez, 1961; McCluskey, 1970; Combes, Stastny, Shorey Eigenbrodt, Barrera, Hull, and Carter, 1971 ; Lewis $\overrightarrow{\mathrm{D}}$ 


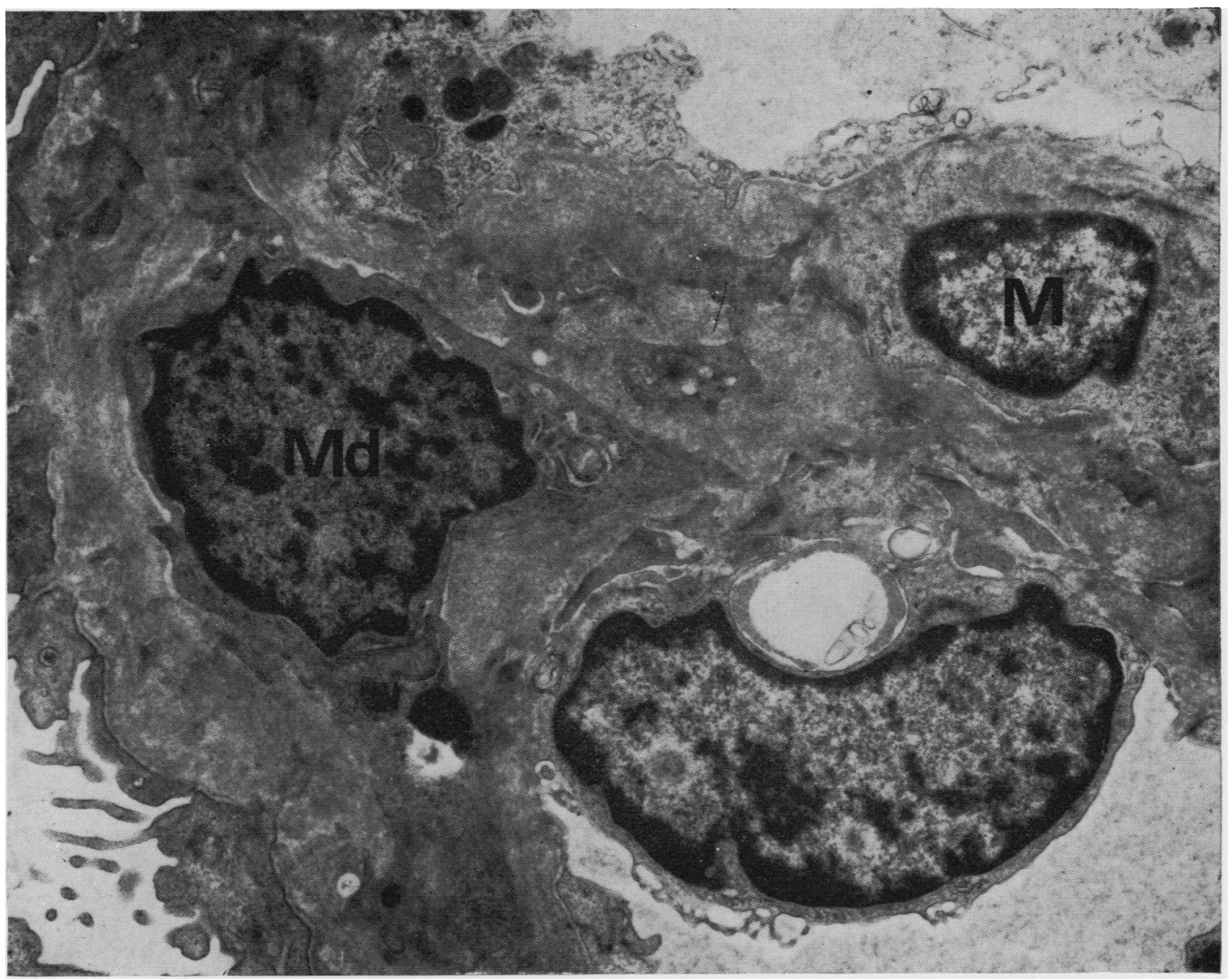

Fig 9 Dark mesangial cell (Md) with dense crenellated nucleus and dark cytoplasm A hyperactive mesangial cell $(\mathrm{M})$ is also present $(\times 12500)$.

Loughridge, and Phillips, 1971; Nowoslawski, Krawczynski, Brzosko, and Madalinski, 1972). In one case, however, in which IgG deposition was equivocal but some fibrinogen was detected, thrombosis of intrarenal venous radicles was seen at biopsy. The association between renal vein thrombosis and membranous glomerular disease is well known (Pollak, Kark, Pirani, Schafter, and Muehrcke, 1956; Tublin, 1968; Giard, Paget, Saout, Croccel, Leroy, and Cousin, 1969), and the present finding suggests a pathogenic mechanism based on the glomerular localization of fibrinogen complexes or aggregates. The coagulation abnormality responsible for the formation of such macromolecules might then be responsible for the thrombosis. Experimental work on this syndrome has, however, concentrated on the production of models with thrombosis as the prime event and membranous glomerulonephritis has not been initiated (Omae, Masson, and Corcoran 1958; Fisher, Sharkey, Pardo, and Vuzevski, 1968; Harris, Ehrenfeld, and Wylie, 1968; Sturgill and Munsie, 1969).

In several cases, immunofluorescence gave positive results for IgG while complement was only equivocally positive, a phenomenon occasionally observed elsewhere (McIntosh, Tinglof, Kaufman, Dornfeld, Gonick, Smith, and Vernier, 1971).

Most workers report minimal mesangial changes in membranous glomerulonephritis (Churg et al, 1965; Rosen, 1971) although Combes et al (1971) noted focal mesangial hypercellularity following membranous deposition of Australia antigenantibody complexes. In the present study, slight or moderate mesangial cell proliferation was often found, and the cellular ultrastructure varied considerably-resting, hyperactive, and dark forms 


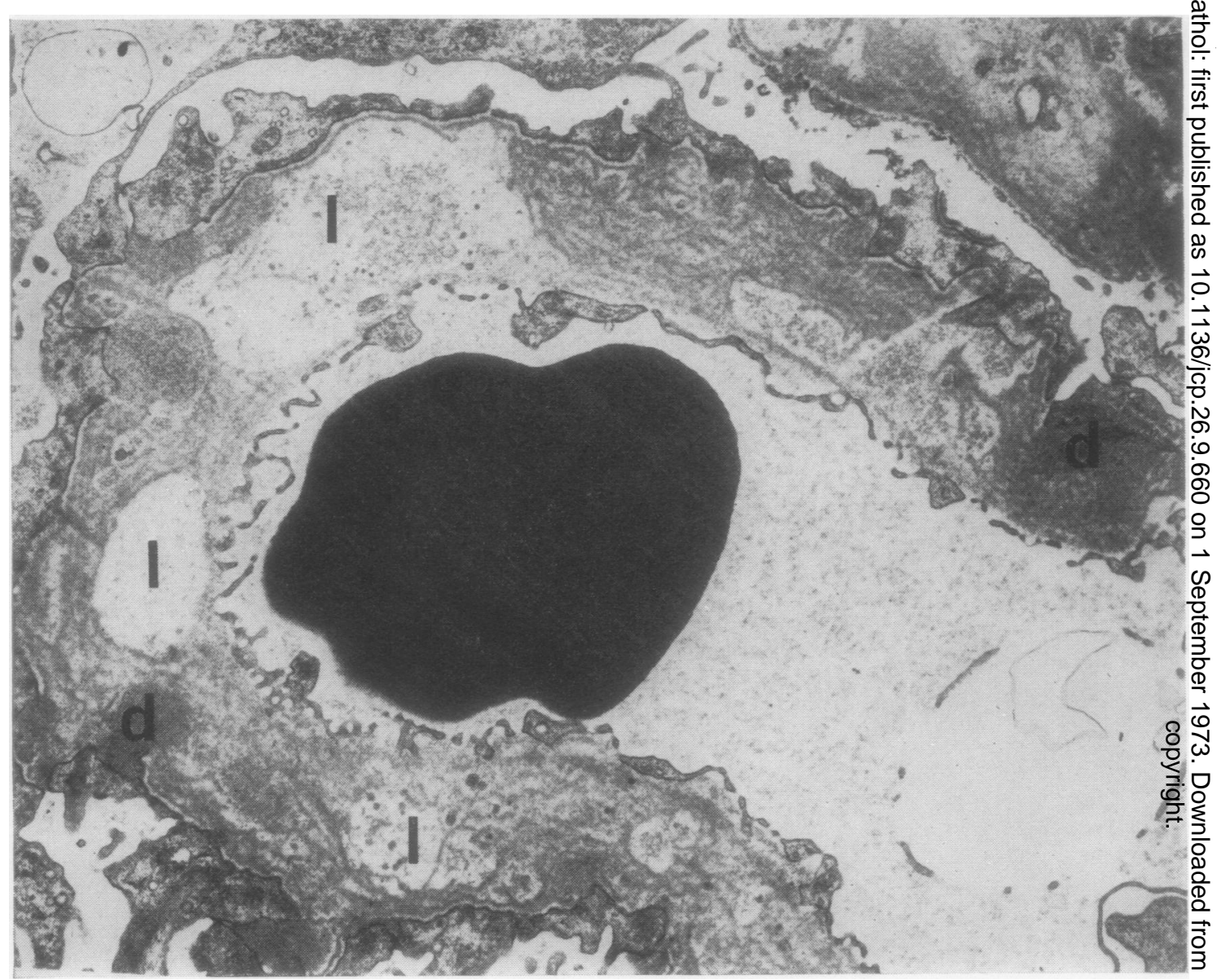

Fig 10 Capillary loop showing subepithelial dense deposits (d) and subendothelial and intramembranous lucent areas (1). Dense granules are scattered within the latter $(\times 12500)$.

being recognized. It could be argued that the shape and density differences were fixation artefacts, for perfusion in situ which gives the best results is not applicable to human biopsy tissues. However, while there was probably some distortion, the variations of cell shape and constituent organelles in different biopsies subject to identical fixation methods supports the contention that mesangial cells exist in several forms.

Knowledge of the ultrastructure of 'normal' mesangial cells has been derived mainly from study of laboratory animals (Latta, Maunsbach, and Madden, 1960; Simon and Chatelanat, 1969). The state of the organelles in normal human mesangial cells (Portch, 1972) indicates low metabolic activity, and in the present investigation comparable cells were found, particularly in biopsies with normal cell numbers and minimal complement deposition. The disease in these cases tended to be of long duration. Cells regarded as hyperactive had cytoplasm of various densities. The main function of the pale forms was thought to be removal of material fromo the glomerular basement membrane and mesangial channels and they had extensive processes, some ofo which spread peripherally into the glomerular basement membrane. The fine structure of the densero cells suggested a secretory role, although evidence of 0 phagocytosis was also seen. Their processes were $\mathrm{W}_{\mathrm{W}}$ confined largely to the axial region. Hyperactive cellso were found in cases involving proliferation and complement deposition.

Mesangial cells can remove material, such as $\stackrel{?}{?}$ ferritin and myeloperoxidase, from the glomerular 0 basement membrane and mesangial matrix (Millerō and Palade, 1964; Graham and Karnovsky, 1966), $\stackrel{\mathbb{\mathrm { Q }}}{\mathrm{Q}}$ and Farquhar and Palade (1962) thought that the 


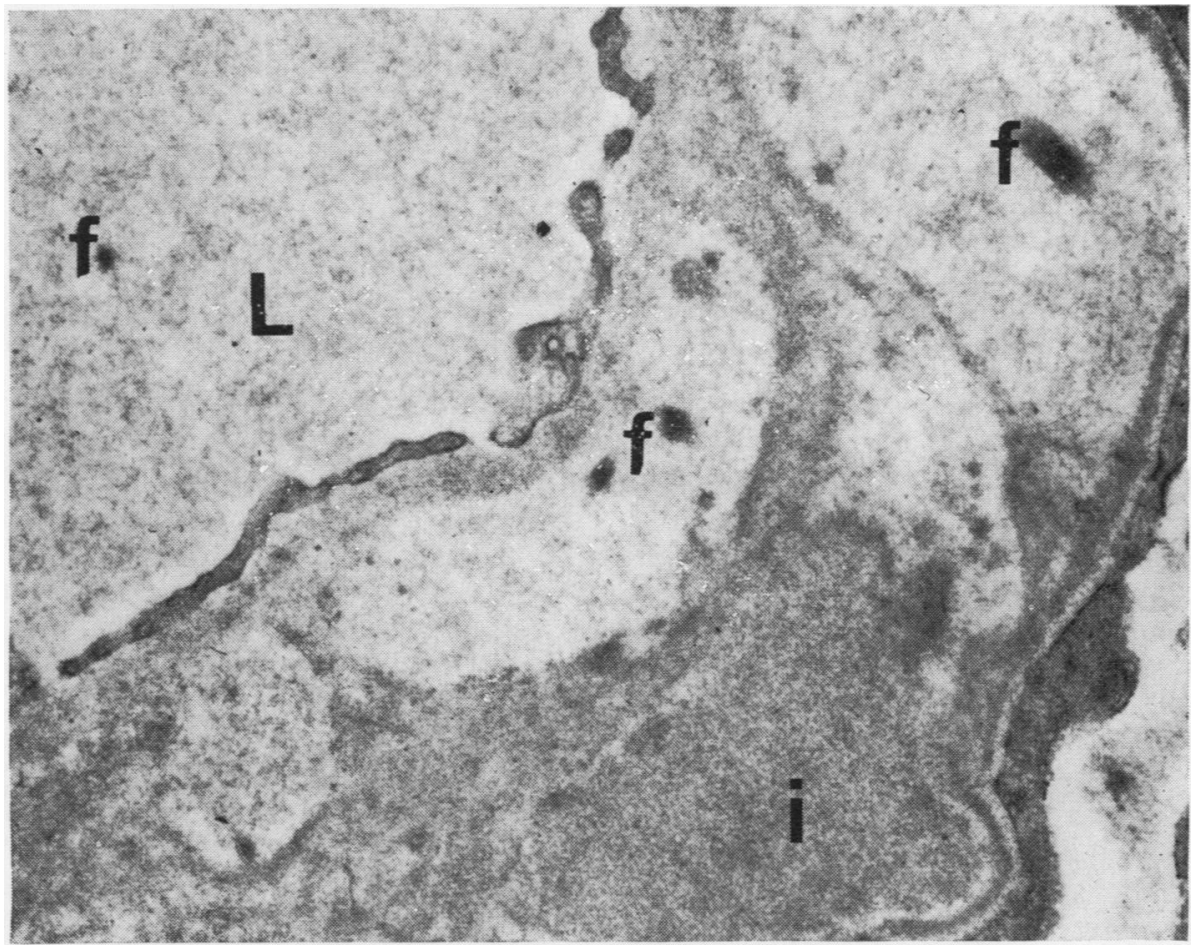

Fig 11 Part of the thickened glomerular basement membrane showing extensive lucent areas, which in this case (no. 2) contain small clumps of fibrin (f). Fibrin can also be detected in the capillary lumen $(\mathrm{L})$. $\mathrm{i}$, intermediate deposit $(\times 30000)$.

chief function was to unclog the glomerular basement membrane, during which activity pseudopodial extensions and cytoplasmic dense body content are increased. It is also believed that mesangial cells secrete the surrounding matrix (Jones, 1963; Simon and Chatelanat, 1969) and that secretion is stimulated by the deposition of materials such as heavy metals or fibrinoid within the mesangial channels (reviewed by Simon and Chatelanat, 1969). The matrix is apparently composed of loosely packed basement membrane-like material, and Foster and Riad (1963) suggested that both structures were composed of collagen surrounded by mucoid material. The former, according to Misra and Berman (1966), is probably in the form of tropocollagen. Profiles of vesicles fusing with the mesangial cell surface as has been described in fibroblasts during collagen synthesis (Sheldon and Kimball, 1962; Goldberg and Green, 1964; Ross and Benditt, 1965; Bloom and Fawcett, 1968) were not widespread in the present study and were seen only in dense hyperactive cells.

The degree of mesangial thickening was related to the duration of the disease and the patient's age, a phenomenon noted in rats by Latta (1961). Endo- thelial cells may also contribute to the matrix as they are reputed to secrete basement membrane elsewhere in the body (Ham, 1969).

Dark mesangial cells, which were found in all biopsies, especially in those with large complement deposits, were interpreted as undergoing shrinkage and degeneration. The role of complement in the production of glomerular damage is poorly understood, although complement fixation is known to promote the release of lysosomal enzymes (Henson, 1972). Free activated components and fragments of complement may also be released during or following complement fixation (Ingram, 1972), and substances inducing contraction of smooth muscle may be produced (Nelson, 1965). Furthermore, cells of the reticuloendothelial system, which probably includes mesangial cells, are stimulated to phagocytose complexes partly by complement-dependent adherence (Henson, 1972).

In the present study, mesangial cell proliferation was generally associated with complement deposition but it is not clear why this should be so. It might represent a response to an increased phagocytic workload, or to mild damage stimulating the cells to 
divide, with more severe damage leading to shrinkage and degeneration.

Membranous glomerulonephritis is a chronic disorder of insidious onset. By the time it has produced overt clinical symptoms, there is usually significant glomerular damage mainly in the form of thickened capillary walls. Our findings suggest, however, that the mesangial cells, hitherto largely overlooked in this nephropathy, have a contribution to make to its evolution.

The patients whose biopsies are discussed in this paper were under the care of Professor D. A. K. Black and $\mathrm{Dr} \mathrm{N}$. Mallick, the latter being responsible for taking the renal specimens. We are indebted to both for permission to publish our results. We also wish to thank Mrs R. Stafford and Mrs G. Moudgil for valuable help in tissue preparation and Mrs $J$. Sellar for typing the manuscript. This work was financed by the United Manchester Hospitals Research Grants Fund.

\section{References}

Bloom, W., and Fawcett, D. W. (1968). A Textbook of Histology, 9th ed., pp. 139-141. Saunders, Philadelphia.

Brewer, D. B. (1964). Renal Biopsy, p. 34. Arnold, London.

Churg, J., Grishman, E., Goldstein, M. H., Yunis, S. L., and Porush, J. G. (1965). Idiopathic nephrotic syndrome in adults: a study and classification based on renal biopsies. New Engl. J. Med., 272, 165-174.

Combes, B., Stastny, P., Shorey, J., Eigenbrodt, E. H., Barrera, A., Hull, A. R., and Carter, N. W. (1971). Glomerulonephritis with deposition of Australia antigen-antibody complexes in glomerular basement membrane. Lancet, 2, 234-237.

Coons, A. H., and Kaplan, M. H. (1950). Localization of antigen in tissue cells. II. Improvements in a method for the detection of antigen by means of fluorescent antibody. J. exp. Med., 91, $1-13$.

Dixon, F. J., Feldman, J. D., and Vazquez, J. J. (1961). Experimental glomerulonephritis: the pathogenesis of a laboratory model resembling the spectrum of human glomerulonephritis. J. exp. Med., 113, 899-920.

Ehrenrech, T., and Churg, J. (1968). Pathology of membranous nephropathy. In Path. Ann., edited by S. C. Sommers, pp. 145-186. Butterworths, London.

Farquhar, M. G., and Palade, G. E. (1962). Functional evidence for the existence of a third cell type in the renal glomerulus. Phagocytosis of filtration residues by a distinctive third cell. J. Cell Biol., 13, 55-87.

Fisher, E. R., Sharkey, D., Pardo, V., and Vuzevski, V. (1968) Experimental renal vein constriction. Its relation to renal lesions observed in human renal vein thrombosis and the nephrotic syndrome. Lab. Invest., 18, 689-699.

Foster, C. L., and Riad, Z. M. (1963). Some staining properties of the glomerular constituents in normal rabbits. J. Anat. (Lond.), 97, 403-407.

Giard, P., Paget, M., Saout, J., Croccel, L., Leroy, J. P., and Cousin, P. (1969). Syndrome néphrotique par thrombose unilatérale des veines rénales d'origine traumatique. J. Sci. mêd. Lille, 87, 119-141.

Goldberg, B., and Green, H. (1964). An analysis of collagen secretion by established mouse fibroblast lines. J. Cell Biol., 22, 227-258.

Graham, R. C., Jr., and Karnovsky, M. J. (1966). Glomerular permeability: ultrastructural cytochemical studies using peroxidases as protein tracers. J. exp. Med., 124, 1123-1134.

Ham, A. W. (1969). Histology, 6th ed., p. 218. Pitman, London. Lippincott, Philadelphia.

Harris, J. D., Ehrenfeld, W. K., and Wylie, E. J. (1968). Experimental renal vein occlusion. Surg. Gynec. Obstet., 126, 555-562.
Henson, P. M. (1972). Complement-dependent adherence of cells tơ antigen and antibody. Mechanisms and consequences. In Biological Activities of Complement, edited by D. G. Ingram, pp. 173-201. Krager, Basel.

Heptinstall, R. H. (1966). Pathology of the Kidney, pp. 363-369心 Churchill, London. Little, Brown, Boston.

Ingram, D. G. (1972). Complement-induced changes in membrane surface properties. In Biological Activities of Complement? edited by D. G. Ingram, pp. 170-172. Krager, Basel.

Jones, D. B. (1963). The nature of scar tissue in glomerulonephritis Amer. J. Path., 42, 185-199.

Kawano, K., Arakawa, M., McCoy, J., Porch, J., and Kimmelstiel, Pญ (1969). Quantitative study of glomeruli. Focal glomerulones phritis and diabetic glomerulosclerosis. Lab. Invest., 21, $269 \overrightarrow{0}$ 275.

Latta, H. (1961). Collagen in normal 'rat lglomeruli. J. Ultrastruct $\overrightarrow{1}$ Res., 5, 364-373.

Latta, H., Maunsbach, A. B., and Madden, S. C. (1960). The centro lobular region of the renal glomerulus studied by electron microscopy. J. Ultrastruct. Res., 4, 455-472.

Lewis, M. G., Loughridge, L. W., and Phillips, T. M. (1971). Immuno logical studies in nephrotic syndrome associated with extrarenato malignant disease. Lancet, 2, 134-135. Luft, J. H. (1961). Improvements in epoxy resin embedding methods
J. biophys. biochem. Cytol., 9, 409-414.

Mandalenakis, N., Mendoza, N., Pirani, C. L., and Pollak, V. EO (1971). Lobular glomerulonephritis and membranoproliferative glomerulonephritis: a clinical and pathologic study based on renal biopsies. Medicine (Baltimore), 50, 319-355.

McCluskey, R. T. (1969). Immunopathologic mechanisms in huma renal diseases. In International Convocation on Immunology Buffalo, N. Y., 1968, pp. 300-312. Krager, Basel, and New York

McCluskey, R. T. (1970). Evidence for immunologic mechanisms if several forms of human glomerular disease. Bull. N.Y. Acad Med., 46, 769-788.

McCluskey, R. T., and Vassalli, P. (1969). Experimental glomerplaco diseases. In The Kidney, edited by C. Rouiller and A. F.'Muger Vol. II, pp. 100-106. Academic Press, New York and Lon

McCluskey, R. T., Vassalli, P., Gallo, G. R., and Baldwin, D- $S \square$ (1966). An immunofluorescent study of pathogenic mechan in glomerular disease. New Engl. J. Med., 274, 695-701.

McIntosh, R. M., Tinglof, B., Kaufman, D., Dornfield, L., Gonick H., Smith. F. G., and Vernier, R. L. (1971). Immunohistology ip renal disease. Quart. J. Med., 40, 385-390.

Miller, F., and Palade, G. E. (1964). Lytic activities in renal protei absorption droplets. An electron microscopical cytochemicał study. J. Cell Biol., 23, 519-552.

Misra, R. P., and Berman, L. B. (1966). Studies on glomerular base ment membrane. I. Isolation and chemical analysis of normat glomerular basement membrane. Proc. Soc. exp. Biol. (N.Y. 122, 705-710.

Nelson, R. A., Jr. (1965). The role of complement in immune phenom ena. In The Inflammatory Process, edited by B. W. Zweifacfof L. Grant, and R. T. McCluskey, p. 862. Academic Press, Ne of York and London.

Nowoslawski, A., Krawczynski, K., Brzosko, W. J., and Madalinsk?. K. (1972). Tissue localization of Australia antigen immurg complexes in acute and chronic hepatitis and liver cirrhosis Amer. J. Path., 68, 31-56.

Omae, T., Masson, G. M. C., and Corcoran, A. C. (1958). Exper? mental production of nephrotic syndrome following renal vein constriction in rats. Proc. Soc. exp. Biol. (N.Y.), 97, 821-825

Pease, D. C. (1964). Phosphotungstic acid stain. In Histologic Techniques for Electron Microscopy, 2nd ed., pp. 236-239. Academic Press, New York.

Pollak, V. E., Kark, R. M., Pirani, C. L., Schafter, H. A., and Muehrcke, R. C. (1956). Renal vein thrombosis and the neplis rotic syndrome. Amer. J. Med., 21, 496-520.

Portch, P. (1972). Personal observation.

Reynolds, E. S. (1963). The use of lead at high $\mathrm{pH}$ as an electro opaque stain in electron microscopy. J. Cell. Biol.,117,208-21

Rhodin, J. A. G. (1962). Fine structure of vascular walls in mammas with special reference to smooth muscle component. Physiō Rev., Suppl., 5, 48-87.

Rosen, S. (1971). Membranous glomerulonephritis: current statứs. Hum. Path., 2, 209-231.

Ross, R., and Benditt, E. P. (1965). Wound healing and collagen formation. V. Quantitative electron microscope radio-aut $\vec{\phi}$ graphic observations of proline- $\mathrm{H}^{3}$ utilization by fibroblasts. 栊 Cell. Biol., 27, 83-106. 
Sheldon, H., and Kimball, F. B. (1962). Studies on cartilage. III. The occurrence of collagen within vacuoles of the Golgi apparatus. J. Cell Biol., 12, 599-613.

Simon, G. T., and Chatelanat, F. (1969). Ultrastructure of the normal and pathological glomerulus. In The Kidney, Vol. 1, edited by C. Rouiller and A. F. Muller, pp. 271-272, 312-322. Academic Press, New York.

Sturgill, B. C., and Munsie, W. J., (1969). Renal vein ligation and proteinuria in the rat. Fed. Proc., 28, 421.

Trump, B. F., and Bulger, R. E. (1968). Morphology of the kidney. In Structural Basis of Renal Disease, edited by E. L. Becker, pp. 6-11. Harper and Row, New York.

Tublin, I. N. (1968). Renal vein thrombosis and the nephrotic syndrome in an adult. Med. Ann. D.C., 37, 530-535.

Watson, M. L. (1958). Staining of tissue sections for electron microscopy with heavy metals. J. biophys. biochem. Cytol., 4, 475-478. 